\title{
Persuasive Strategies Towards Racial Appeal in Tony Morrison's the Bluest Eye
}

\author{
Somayeh Shabani* \\ Tabriz Azad University, Iran
}

Corresponding Author: Somayeh Shabani, E-mail: Mahsashabani@yahoo.com

\section{ARTICLE INFO}

Article history

Received: July 28, 2017

Accepted: October 17, 2017

Published: January 05, 2018

Volume: 7 Issue: 1

Advance access: December 2017

Conflicts of interest: None

Funding: None

\begin{abstract}
Racism is the main theme in Toni Morisson's The Bluest Eye. The little black girl's long lasting yearn for blue eyes has been linked to the standards of America's society in 1940's which associated beauty to being white. Although instances of racism are rampant throughout the story, previous studies have not attempted to determine the type of persuasive strategies used by Toni Morrison to justify racism in the novel. In this paper, the author made use of Aristotle's concepts of ethos, logos, and pathos, as 3 main dimensions of persuasion to determine the strategies used in the novel by the narrator-Claudia. Descriptive qualitative analysis of the novel's text revealed that the author has made use of all these strategies. Pathos was observed in form of feelings of fear, anger and hatred. Logos was observed in the logic of the grown up society of America about being white and ethos was found among the black who themselves credited the whites over their own race.
\end{abstract}

Key words: Racism, Persuasive Strategies, Ethos, Logos, Pathos

\section{INTRODUCTION}

Toni Morrison, the winner of noble prize for literature, is a contemporary American novelist known for using epic themes and vivid dialogues in her novels (Middleton 2016). She was named as a "National Figure in America's National Literature" by the New York review of books. Throughout her writing, Morrison has attempted to explore the life, culture and experiences of African Americans (Rigney 1991). Her firs novel "The Bluest Eye" which was published in 1970 is an example of such endeavor in which the author attempts to depict the misery brought upon African American in the society of America during America's great depression in 1940s.

As reported by (Rothschild 2013), in 1921 prices of stock in New York exchange stock market tumbled to less than half of their original value. By 1932, nearly 1 out of every 4 American was Unemployed. This made leaving for both American and immigrants a real challenge. Despite great depression, racism remained throughout the country. Racism was felt by the narrator of the study, Claudia who is a nine-year old Black girl leaving with her family in Ohio. Although most of the study is centered on Pecola, another black girl in the story, Claudia manifests her hatred towards the white society of America in various parts of the novel. Previous studies have had focus on racism in the story; however, how the main character perceives racism and unveils it to the white society, which can be seen in her thoughts and dialogues, has not been sufficiently attended to. Therefore, this article made use of Aristotle's concept of persuasion to investigate this issue.

\section{The Story}

The story mainly depicts the life of two African American families, the MacTeers and the Breedloves. Pecola, the protagonist of the story is the Breedlove's daughter who is having a tough life. Her drunk father is constantly and harshly fi hting with her mother. Her Brother, Sammy, has run away from home several times, and she is impregnated by her drunk father. She associates all of these harsh events to her own ugliness and wishes to have a pair of blue eyes.

Claudia MacTeer, on the other hand, is having a more stable life. Her mother can afford to take care of her and her sister although they do not live a lavish life. At one point in the story, Claudia and her sister Fredia attempt to help Pecola to safely deliver her baby. Finally, Pecola's father commits suicide, Pecola' baby dies and she goes mad believing that she has blue eyes.

\section{Racism in American Literature}

Sundquist (1993) assumed that the making of American literature is race. As a result, following American literature, one can realize what has changed in the life of Americans and what have continued to plague the culture. Racism has been reflec ed in a number of literary works in American literature. For example (Leonard, 1997, Butler-Evans 1989; Ernest 1995; Davis 2000; Wonham 2004). The results of the attempt to save and redeem the face of black Americans was the inception of a subgenre- Black American Literature (Ogene 2013). Among many literary works that 
have attended to the concept of racism in black American literature, Toni Morrison has adopted almost a distinctive approach. In $18^{\text {th }}$ century and afterwards many authors attempted to expose sad situations in which the black were abused by the white, for example "The Sport of the Gods" by Paul Laurence Dunbar. However, Morrison, in the bluest eye, assumed that people are the cause of their own misery and misery in not brought upon them by others. Therefore, the main characters in the story are all black who at times associate negative features to being black such as being ugly or dirty. The author also reveals various instances of hatred towards the white that exist among the black in an attempt to show that the hatred in America's 1940 society has been bi-directional among the black and whites. Such distinctive features make this novel a worthy novel to be further delved into.

\section{Aristotle's Persuasive Strategies}

In this paper, Claudia's narration is analyzed to find out how the author attempts to convince the readership about the racial appeal with existed in the society. In other to do so, Aristotle's Persuasive Model was opted and used. The model compromises of 3 main elements, ethos, logos and pathos. According to Sabrina (2016), Aristotle assumed that effective persuasion takes place in one of the 3 forms mentioned above. Ethos refers to the credibility of the communicator; it reveals the trustworthiness of the source and adds to the value of claim. Logos refers to how logical and well-presented the message is by presenting facts and fi ures, reasoning and attempting the make sense to the interlocutor. Finally, pathos is an attempt to touch one's emotion and feeling. Examples of pathos can be narrating a compelling story, visualizing a striking picture, or creating extreme feelings such as anger or fear.

Racism is a complex issue in the novel. Although the novel is rampant with examples of racist thought among people of color, the main characters of the study are black and the white characters are in spectrum. Whiteness is generally a sense of worthiness among the characters which is associated with cleanliness. An example is when Claudia, the narrator is sick. Her mother associates sickness to uncleanliness and being black. Others occasions in the novel show that racism exists within the characters, families and community in the novel. An example is accepting beauty icons such as Shirley Temple whose photo appears on the cup in the story. Among previous studies that have studied racism in the bluest eye, the issue of how the author attempts to persuade the readership about the existence of racism among the characters, especially with regard to Aristotle's persuasive model is not attended to. Therefore, the author of this paper was motivated to study racism in the novel from this perspective.

\section{Research Design}

Descriptive qualitative analysis of text was opted as the main approach to analysis of the novel. Instances of Claudia's dialogues and soliloquies were selected and categorized into 3 main taxonomies based on Aristotle's' Persuasive model.
This resulted in accumulation of 3 types of data, i.e., ethos, logos, pathos.

\section{DISCUSSION}

\section{Claudia's Character}

Claudia is a lucky girl as unlike Pecola, the protagonist, she leaves in a stable family.

Claudia has a sensitive and different character from other characters in the story. She frequently states her feelings about the happening around her and her despise from the white society of America can be very well understood in her narrations. Examples of this hatred can be found in the way she describes the white neighbor girl sitting in his father's car and eating bread with butter or in assertion of her anger about the picture of Shirley Temple (a white celebrity) on the cup.

Many assume that Morrison has attempted to mirror her childhood in Claudia's character as the author has named her own hometown. In addition, Morrison had been around 9 years old when the story took place in 1940s.

\section{Datum 1 (Ethos)}

One of the common strategies to show racism is by giving credibility to the white society by black people. Claudia asserted this issue when she received a white doll with blue eyes for Christmas; assuming that older people adore the white and think what they liked suits the children. Indeed, the adults' decision clearly represents the thought of black Americans about the white society.

"From the clucking sound of adults I knew that the doll represented what they thought was my fondest wish" (p.21).

Credibility is given to whiteness in other parts of the story as narrated by Claudia. For example when pecola constantly prays for a pair of blue eyes to look like the white.

"Each night, without fail, she prayed for blue eyes. Fervently, for a year she had prayed"(p.46).

Another example of giving credibility to the white as narrated by Claudia is when Pecola pays a visit to 3 white prostitutes living upstairs from the MacTeers. Pecola likes the prostitutes as she thinks they are the only whites who see her, although she is used by the prostitutes rather than respected. However, the credibility is given to the whites by Pecola.

"Three whores lived in the apartment above the Breedloves' storefront. China, Poland, and Miss Marie. Pecola loved them, visited them, and ran their errands. They, in turn, did not despise her" (p.50).

In another grow up dialogue when Claudia's mother is talking to a friend about Mr. Henry, her black roomer, his divorce is discussed. They associate his divorce with the cleanliness of the former wife. In this sense they narrator assumes that the black ladies have believed that cleanliness is not a black feature rather associated with the whites.

"That's the one. Well, somebody asked him why he left a nice good church woman like Della for that heifer. You know Della always did keep a good house. And he said the honestto-God real reason was he couldn't take no more of that violet 
water Della Jones used. Said he wanted a woman to smell like a woman. Said Della was just too clean for him" (p.13).

Another example of giving credit to the white is when Claudia is describing a new white girl at school. She describes her from an inferior position and associated many good features such as good smell, richness, and being neat to being white.

"Fluffy sweaters the color of lemon drops tucked into skirts with pleats so orderly they astounded us. Brightly colored knee socks with white borders, a brown velvet coat trimmed in white rabbit fur, and a matching muff. There was a hint of spring in her sloe green eyes, something summery in her complexion, and a rich autumn ripeness in her walk" (p.62).

\section{Datum 2 (Logos)}

Throughout the story, Toni Morrison attempts to depict a sense of inferiority that the black characters feel about themselves. The author believes that racism does not occur only in the interactions with the white society, but also by the way the black feel about themselves. Therefore, the story is dominated by the blacks' logic about themselves. One example is when Claudia is describing the grown ups' logic about their children's sickness:

"Our illness is treated with contempt, full black draught, and caster oil that blunts our minds" (p.10).

Claudia's mother, Mrs. MacTeer, associates her daughter's sickness to uncleanliness; believing that the reason white children do not feel sick is that they are clean. This logic is also depicted in other parts of the story.

Another instance of logical conclusion that the white have superiority over the black is when Claudia asserts the society's view over being white. In fact, the author attempts to show that the socity has accepted whites as standard. This logic is shown in the following sentences:

"Adults, older girls, shops, magazines, newspapers, window signs-all the world had agreed that a blue-eyed, yellow-haired, pink-skinned doll was what every girl child treasured" (p20).

\section{Datum 3 (Pathos)}

There are several examples in the novel which show racism from the point of view of Claudia. In some occasions the author uses the nine-year-old girl's feeling to reveal racism and to show how the white society of America is either fina cially, or emotionally detached from the Black portion of the society. For example, Claudia and her older sister Frieda are introduced in the story while looking at a white girl setting in her father's car. The white girl is eating bread with butter which Claudia and her sister cannot afford to eat. Claudia describes this scene in the following way:

"We stare at her, wanting her bread, but more than that wanting to poke the arrogance of out of her eyes and smash the pride of ownership that curls her chewing mouth.... When she comes out of the car, we will beat her up" (p.9).

Another example of anger towards the white is when Claudia torn off her white doll. She describes the scene as she points to parts of the body of a white person.
"Traced the turned-up nose, pokes the glassy blue eyeballs, twisted the yellow hair. I could not love it" (p.21).

Other than feeling of anger, as depicted in the example above, there are examples in which Claudia shows hatred towards the white Americans as they resemble beauty in the society. Her reaction to Fredia's and Pecola's fondness of Shirley's photo on the cup is depicted in the following sentences:

"I couldn't join them in their adoration because I hated Shirley... before that, I had felt a stranger, more frightening thing than hatred for all the Shirley Temple's in the world" (p.19)

Claudia admits that Shirley is beautiful, but cannot accept all the credit given to her by her sister and Pecola; therefore she prefers Jane Withers. The fact that Jane Withers is another white actress, however, does not resemble the fondness of the black girl for white movie stars. Indeed, Claudia despises all white characters. Her extreme hatred towards Shirley Temples causes her to choose Jane Withers over Shirley Temples. She also asserts that:

"But before that I had felt a stranger, more frightening thing than hatred for all of the Shirley Temples of the world" (p.19).

Feeling of hatred towards the white is also stated by Claudia after destroying the white doll given to her by adults. Her hatred from the white is not satiated by murdering the doll and she yearns for tearing up white girls with an axe:

"I destroyed white baby dolls. But the disremembering of the dolls was not the true horror. The truly horrifying thing was the transference of the same impulses to little white girls. The indifference with which I could have axed them was shaken only by my desire to do so" (p.22).

Feeling of fear from the white is another type of emotion that the author attempts to present to the audience through Claudia's narration. When Claudia is describing the white doll given to her by adults she admits that the beauty of the doll is frightening:

"Raggedly Ann doll usually, but they were out of the question. I was physically revolted and secretly frightened of those round moronic eyes. The pancake face, and orange worms hair" (p.19).

\section{CONCLUSION}

Toni Morrison depicts the racial appeal given to the white through vivid dialogues and soliloquies in the Bluest Eye. Various samples of the text depicting the credibility given to the white by the black and how the black African along with the society had logically come to the conclusion that the white features are what the society needs were given in the story. In addition, the society's logic about white people was represented and categorized under the heading logos. Finally, the narrators feelings about being black and the white community was revealed through anger, fear and hatred.

\section{REFERENCES}

Butler-Evans, Elliott. Race, Gender, and Desire: narrative strategies in the fiction of Toni Cade Bambara, Toni Morrison, and Alice Walker. Philadelphia, PA: Temple U Press, 1989.Print. 
Davis, Jane. The white image in the black mind: a study of African American literature. Westport,CT: Greenwood Press, 2000. Print.

Ernest, John. Resistance and reformation in nineteenth-century African-American literature: Brown, Wilson, Jacobs, Delany, Douglass, and Harper. Jackson, MS: U of Mississippi, 1995. Print.

Leonard, Anne. Into darkness peering: race and color in the fantastic. Westport, CT: Greenwood Press, 1997. Print.

Middleton, David L., ed. Toni Morrison's fiction: contemporary criticism. Vol. 30. Routledge, 2016.
Ogene, Ms. "Black American Literature and the Problem of Racism, Slavery and Oppression in the Post Slavery Era: A Reappraisal of Dunbar's The Sport of the Gods." UJAH: Unizik Journal of Arts and Humanities 14.1 (2013): 75-95. Rigney, Barbara Hill. The voices of Toni Morrison. The Ohio State University Press, 1991.

Rothschild, Emma. Economic sentiments. Harvard University Press. 2013.

Sundquist, Eric J. To wake the nations: race in the making of American literature. Harvard University Press, 1993.

Wonham, Henry B. Playing the races: ethnic caricature and American realism. Oxford University Press, 2004. 